\title{
DA POLÍTICA DE DEUS: UM ENSAIO SOBRE DEMOCRACIA E RELIGIÃO
}

\author{
José Bittencourt Filho ${ }^{1}$
}

RESUMO: Considerando a religiosidade como um traço marcante do perfil cultural latino-americano, alguns fenômenos parecem evidenciar a escolha das organizações religiosas como um novo canal de participação política, tanto em função dos obstáculos erigidos pelo sistema, quanto pela obsolescência dos canais historicamente utilizados. Este breve ensaio pretende verificar a hipótese de que essa nova alternativa não só faz parte de uma nova concepção da relação entre religião e política, como, em vez de contrastar, reforça a lógica sistêmica. E tudo isso com graves desdobramentos, quer para a democracia vigente, quer para o novo projeto democrático que urge ser elaborado pelos povos e países excluídos e/ ou submetidos à nova face da dominação.

Palavras-chave: Democracia. Participação política. Religião. Religiosidade. Neoliberalismo

ABSTRACT: If we consider religiosity as an important mark of Latin American cultural profile, some phenomena seems to put in evidence the choice of religious organization as a new channel of political participation, as because the obstacles built by the system, as because the obsolescence of the historically used channels. In this paper, the hypothesis to be checked is that this new alternative is not only part of a new conception of relation between religion and politics, as, instead of confront, reinforce sistemical logics. And all this with the consequences, whether to actual democracy, or to a new democratical project, which must be elaborated by excluded and/or submitted people and countries to the new face of domination.

Keywords: Democracy. Participation Politics. Religiosity. Neoliberalism. 


\section{INTRODUÇÃO}

Conceito de participação política pertence ao plano da ação social. Sobretudo no seu uso pela ciência política, ele classifica um conjunto de atividades diretamente vinculadas a práticas específicas da democracia representativa ocidental. Assim sendo, observado em seus aspectos empíricos, irá refletir a maturidade ou não de uma realidade democrática dada. Nos países periféricos do capitalismo ocidental, existe uma série de fatores que dificultam, quando não impedem, uma participação política satisfatória, que vai desde as taxas de analfabetismo e do tempo social ocupado com a obtenção da sobrevivência, até a carência de estruturas, institucionalizadas ou não, que favoreçam esse exercício de cidadania.

Ademais, não tem sido fácil criar uma tipologia unívoca das modalidades de participação, porquanto, no âmbito das ciências sociais, a compreensão e a interpretação das condutas participativas costumam estar associadas a pendores ideológicos e tendências teóricas nem sempre convergentes ou consensuais, motivo pelo qual, até o momento, não se dispõe de uma teoria exaustiva da participação política Merece registro um aspecto adicional não menos importante: a concepção de participação política necessariamente comporta, como pressuposto, um modelo ideal de democracia. Além disso, a experiência tem mostrado que a participação propriamente dita se restringe sempre a um número reduzido de pessoas e até mesmo confunde-se com militância; enquanto, no plano das massas, o que se verifica, quando muito, são eventos de mobilização.

Nesta passagem de século e de milênio, nos quadrantes latinoamericanos, vive-se uma crise sem precedentes no tocante à legitimidade e à eficácia da democracia representativa burguesa. Após um decurso de regimes autoritários, a redemocratização não logrou prover às nações do Continente a satisfação dos direitos sociais mais rudimentares. Acresce o advento da globalização com sua inerente modernização compulsória, que desorganizou e tornou ainda mais dependentes as frágeis economias nacionais. Uma recente pesquisa teria efetuado uma constatação alarmante, qual seja, a de que, em face da insegurança quanto ao presente e ao futuro, a maioria dos latinoamericanos daria preferência a regimes autoritários economicamente 
eficazes, do que a democracias incapazes de solucionar o problema da pobreza endêmica e da falta de oportunidades de ascensão social. ${ }^{2}$

Com efeito, cresce em proporções geométricas o desinteresse pela política em geral, e pela política institucional em particular, em virtude da sucessão de escândalos de corrupção, do distanciamento notório entre representantes e representados e da submissão dos aparelhos de Estado à lógica do poder econômico nacional e estrangeiro. Assim, em primeiro plano, faz-se necessário reconhecer que o decréscimo da participação política nos países pobres decorre de uma decadência real do modelo clássico de representatividade. Acresce que a situação se agrava quando se sabe da sensação de impotência dos cidadãos perante o rumo dos acontecimentos nos níveis estrutural e conjuntural, como um subproduto da nova ordem financeira globalizada.

Nesta altura, é oportuno assinalar que o fim da Guerra Fria, a consolidação da hegemonia do capitalismo, os avanços tecnológicos extraordinários e céleres, sobremaneira no campo da comunicação social, operaram uma mudança substancial no cenário da luta ideológico-política. As formas de mobilização, organização e enfrentamento, por intermédio dos partidos progressistas, dos sindicatos e dos movimentos sociais, arrefeceram e perderam grande parte de sua relevância e eficácia.

Com a instauração da chamada "sociedade da informação", surgiram novas estratégias, novos instrumentos e novos protagonistas responsáveis pelo processo de dominação em curso.

Nesse novo cenário, os meios eletrônicos de comunicação e os mass media expandiram a informação tendenciosa e a manipulação do conteúdo dos fatos, numa escala jamais dantes verificada, como tão bem sintetiza Gilberto Dupas (2001, p. 42), tomando como exemplo a tecitura de redes planetárias, a saber:

“[...] Elas constituem a nova morfologia social das nossas sociedades, e a difusão de sua lógica altera radicalmente a operação e os resultados dos processos produtivos e o estoque de experiência, cultura e poder. Nas redes o poder desloca-se para os que detêm o controle dos fluxos. Ordenar uma rede, estar presente nela e operar a dinâmica de sua interrelação com outras redes define as estruturas de 
dominação e transformação de nossa sociedade. Na rede, prioriza-se a morfologia sobre a ação social.

Contudo, com o decréscimo dos meios e instrumentos historicamente consagrados, sob a égide de novos paradigmas, vão sendo esboçadas expressões coletivas anti-sistêmicas, ainda que lenta e timidamente. Nesse quadro, os analistas buscam precisar quais seriam as formas mais criativas e originais de contraposição criadas pelos grupos humanos à globalização financeira, à modernização compulsória, à mundialização cultural e à imposição do pensamento único.

Considerando a religiosidade como um traço marcante do perfil cultural latino-americano, alguns fenômenos parecem evidenciar a escolha das organizações religiosas como um novo canal de participação política, tanto em função dos obstáculos erigidos pelo sistema, quanto pela obsolescência dos canais historicamente utilizados. Neste breve ensaio, pretende-se verificar a hipótese de que essa nova alternativa não só faz parte de uma nova concepção da relação entre religião e política, como, em vez de contrastar, reforça a lógica sistêmica. E tudo isso com graves desdobramentos, quer para a democracia vigente, quer para o novo projeto democrático que urge ser elaborado pelos povos e países excluídos e/ou submetidos à nova face da dominação.

Tal verificação se dará a partir do enfoque do estágio inicial, ou seja, do fundamento e das motivações confessas, e nele serão privilegiados os aspectos referentes ao plano da justificação simbólica e/ou da ideologia. Na atualidade, é esse o campo de batalha de onde quem sai vitorioso conquista os "corações e as mentes". Trata-se do terreno onde prevalecem o poder simbólico, a violência simbólica e a dissidência utópica como personagens principais. Isso significa também que o enfoque irá privilegiar o aspecto da mobilização, etapa inerente e fundamental de qualquer empenho participativo.

Para tanto, a estrutura do artigo ficou assim estabelecida: no item 1, procurou-se enumerar, explicar e exemplificar empecilhos à participação política no panorama da nova ordem internacional globalizada; o item 2 apresenta um arrazoado acerca das correlações entre religião e poder, bem como entre estes e a participação política, em especial na América Latina, a partir dos anos de 1970; o item 3 privilegiou um exemplo brasileiro recente de participação política dos evangélicos e 
ainda resgatou uma parte da história também recente da participação política dos cristãos, bem ou malsucedida, dependendo do ponto de vista, ocorrida tanto em solo nacional quanto entre os vizinhos latinoamericanos; o item 4 traça paralelos entre o expansionismo evangélico e a nova concepção de sociedade civil, bem como constrói um nexo entre esses temas e a democracia ocidental; já no item 5, analisa-se o papel das organizações não-governamentais (ONGs) em todo esse processo, e o item 6, à guisa de conclusão, sintetiza os principais argumentos desenvolvidos e retoma a hipótese.

\section{EMPECILHOS À PARTICIPAÇÃO}

Em princípio, a participação política tem sido concebida como uma via alternativa para que indivíduos e grupos alcancem maior inserção social e, mais ainda, como um caminho para a diminuição das injustiças e das desigualdades, na proporção em que amplia a cultura política e envolve mais pessoas e mais interesses nos processos de decisão que afetam a coletividade. Em síntese: sob qualquer circunstância, trata-se de um aprimoramento necessário e desejado da democracia. No cenário neoliberal em que se encontram as sociedades ocidentais, essa via vai se tornando cada vez mais rara, entre outras razões, pela carência de pontos de referência para uma participação política conseqüente.

Tal carência se verifica em virtude tanto da multiplicidade quanto da opacidade dos pólos de poder real, pois, cada vez mais, a política e o poder se afastam, em virtude de uma lógica econômica inexpugnável e pelo surgimento de novos megacentros mundiais de poder, que parecem tornar inexeqüível qualquer proposta alternativa à globalização financeira e à mundialização cultural, elementos constitutivos da identidade do modelo de mercado total. Foi tecida uma rede ideológica e tecnocrática por demais complexa que impede e desestimula a participação política, por meio do despreparo das pessoas para essa expressão de cidadania.

A globalização é problemática e contraditória, na medida em que impõe aos indivíduos padrões e valores até então desconhecidos e dissolve parâmetros de tempo e espaço, já que as mesmas condições técnicas que alimentam a integração e a interdependência sustentam as desigualdades e as sutis estruturas de dominação. Multiplicam-se 
os antagonismos sociais pela privatização crescente, pelo consumismo desvairado e pela massificação alienante, fatores também decisivos no desestímulo à participação política. A fetichização ${ }^{3}$ das mercadorias embota o discernimento, enquanto o predomínio da tecnologia e da razão instrumental escraviza as consciências.

As maiorias encontram-se impedidas de identificar a essência da verdade dos fatos e de construir critérios seguros de interpretação, bem como de identificar as fontes de contra-informação, em virtude da dependência criada em relação à grande mídia, inteiramente alinhada à "receita" neoliberal. No entanto, a participação política permanece sendo o único caminho das pessoas para alcançar um nível satisfatório de autonomia em relação às barreiras impostas pela dinâmica da globalização.

Além do empobrecimento econômico, em face da ameaça do desemprego estrutural, dá-se o empobrecimento político em conseqüência da ânsia pela sobrevivência que tornam secundárias quaisquer lutas por melhores condições salariais e de trabalho. Assim, os trabalhadores perdem a força de enfrentamento ideológico próprio das categorias profissionais organizadas, pois se desvanece o cenário da luta, substituído pela abstração operacional e virtual do mercado. Com isso, tornam-se aparentemente incontornáveis as dificuldades e limitações derivadas do determinismo coletivo, que cerram os caminhos para a participação política.

O neoliberalismo, ao implantar suas políticas em grande escala, aliena os indivíduos dos centros decisórios. As noções de liberdade, democracia e de cidadania vão se deteriorando em virtude do despreparo das pessoas para participar politicamente. Na proporção em que os indivíduos perdem a referência do associativismo e dos laços corporativistas, passam a desvalorizar o equacionamento e o encaminhamento da solução dos problemas sociais e econômicos por intermédio da prática política organizada; com efeito, conscientemente ou não, as maiorias se deslocam da condição de ativistas para a de adesistas.

Ademais, no plano das elites, conservadores e liberais convergem, enquanto os segmentos progressistas permanecem incapazes de produzir um contraponto, e assim apontar novos horizontes de ação e pelo menos o esboço de novos modelos de sociedade e de Estado. Com efeito, vão sendo politicamente dilapidadas as instituições 
estatais a ponto de se tornarem impotentes diante da instalação da lógica neoliberal no interior mesmo da máquina pública, com todos os desdobramentos inerentes.

O discurso neoliberal tem conseguido acessar o imaginário de significativos contingentes humanos de todas as classes sociais, ao introduzir o conteúdo ideológico que responsabiliza o atraso cultural e tecnológico, a corrupção endêmica da máquina estatal e a burocratização, pelas desigualdades, pela concentração de renda, pela exclusão, pela miséria e por outros dramáticos problemas sociais. Com esse expediente, exime de responsabilidade a hegemonia do "capitalismo selvagem" calcado na especulação financeira, na lógica do lucro desmedido e no predomínio do chamado mercado total. A par disso, conseguiu induzir os indivíduos a não perceberem as dimensões globalizadas da existência social, promovendo uma espécie de individualismo virtual que comporta a propriedade de banir as preocupações com a dimensão estrutural da sociedade.

Em suma: a globalização lança o indivíduo num mundo de controvérsias e, mesmo numa crise existencial, pois que o projeta num movimento pendular entre o apelo incessante pela satisfação de todos os desejos de consumo e as dificuldades concretas de realizá-los. Essa "ressaca" emocional constante o distancia da razão e do equilíbrio. Assim, o processo de massificação não só impele ao consumismo, como impede a participação política; que exige racionalidade, autonomia e autodeterminação.

Portanto, a superação das dificuldades, no tocante à participação política no contexto globalizado, só acontecerá quando os indivíduos forem capazes de distinguir entre o que é difundido e o que realmente acontece no plano das interações e relações sociais. Faz-se necessário que conquistem o entendimento político de que o mundo globalizado, dominado pela ciência e pela técnica, pertence também aos seres humanos cidadãos.

\section{DA ALTERNATIVA RELIGIOSA}

Política e Religião sempre caminharam juntas. Desde os primórdios da humanidade, em função da necessidade de coesão social, da conquista e da manutenção da identidade coletiva, ancestralidades e 
símbolos sagrados foram inventados no intuito de prover essa necessidade, a ponto de algumas correntes nas ciências sociais considerarem que a função precípua da Religião fosse apenas e tão-somente sacralizar e legitimar a organização social. Segundo essa visão, tratar-se-ia de fazer corresponder no transcendente às relações sociais como elas se dão e, desse modo, tornar sagradas todas as hierarquias, todos os tipos de divisão social do trabalho, bem como todas as modalidades de distribuição social do prestígio, da riqueza e do poder.

Não faltou quem situasse a Religião como a forma mais acabada de ideologia, ou seja, um mecanismo por meio do qual as relações sociais reais são camufladas e, assim, tornam opacas as diferentes formas de espoliação econômica e de alienação, exercendo a função de um anestésico que diminui nas pessoas o ímpeto para a resistência e para o engajamento nos esforços pela transformação social. Ao longo da história da humanidade, em diferentes civilizações, pode-se constatar a freqüência com que foram instaladas as mais variadas teocracias. A suposta origem divina dos poderes monárquicos e absolutos só sofreu revezes, pelo menos na civilização ocidental, há aproximadamente três séculos, e, com efeito, ainda persiste em diferentes quadrantes do planeta.

No entanto, pode-se afirmar que, no Ocidente, a lenta e gradual laicização do Estado teve como resultado a definitiva separação entre Religião e Política no plano da arquitetura das mundividências. Em outras palavras, pode-se dizer que, geralmente, as alianças que ainda são celebradas no bojo da política institucional se dão apenas como resultado de interesses das classes dirigentes, como também dos interesses das agremiações religiosas; segundo uma lógica corporativista, pragmática e temporária.

Assim, com a racionalização e a secularização da Política, as alianças estratégicas entre Política e Religião foram definitivamente substituídas pelas alianças táticas.

Portanto, no mundo ocidental, com o surgimento e a consolidação do Estado Constitucional laico (mesmo nos casos em que o país possua uma religião oficial), e da hegemonia do Cristianismo, configurou-se um processo de relações entre as instituições políticas e a instituições religiosas, ora de colaboração, ora de conflito. Desse modo, o estudo acerca da clássica relação entre Religião e Política foi se circunscrevendo ao plano filosófico, ao mesmo tempo em que foi 
cedendo espaço às investigações a respeito das (tumultuadas) relações entre Igreja (católica e protestante) e Sociedade (civil e política), cabendo a descrição e a interpretação do fenômeno cada vez mais às chamadas ciências do social.

Entretanto, numa investigação científica sobre essa problemática na conjuntura brasileira atual, faz-se mister contemplar as dimensões política, cultural e sociológica que ora se encontram justapostas, ora se mostram integradas, ora se situam em oposição; sem descurar a autonomia relativa que lhes corresponde. A par disso, dada a complexidade do fenômeno, metodologicamente, faz-se necessário escolher um eixo temático transversal a todas essas dimensões, por intermédio do qual se possa arriscar uma interpretação do momento atual da cultura política brasileira, ainda que parcial.

Desde a década de 1960, a participação política ativa - modalidade específica de participação social - adquiriu prestígio em virtude do anseio democrático então vigente que contrapunha a participação aos processos de massificação (capitalismo) e de centralismo burocrático (comunismo), pois esses últimos seriam empecilhos às maiorias de influírem de algum modo nas decisões econômicas e políticas que lhes afetassem. O pano de fundo desse prestígio crescente é proveniente da concepção de cidadania plena da Revolução Francesa, que principia na extensão de direito de voto a todas as camadas da população e vai até a plena soberania de todos os povos e países em frente às matrizes imperialistas internacionais.

Deve-se ponderar ainda que a participação política de massas é um fenômeno bastante recente, porque só adquire proporções consideráveis a partir do início do século XX. Ademais, a participação ativa e permanente fica restrita a minorias, pois a grande maioria não vai além das eleições e, quando muito, se faz presente apenas esporadicamente em manifestações ou atividades de cunho político. Acresce o problema da desinformação: mesmo nos países com tradição democrática, o nível de interesse pelas questões políticas institucionais se mostra bastante reduzido, a despeito do volume de informações veiculado pelos meios de comunicação social e outros canais de informação. Entre os povos que se situam na periferia do capitalismo, o desinteresse é ainda maior, sobretudo, em virtude das formas declaradas ou sutis de autoritarismo, corporativismo e de corrupção, nos diversos escalões da administra- 
ção pública, sem contar que a segurança econômica costuma ser mais valorizada que as liberdades públicas.

A bem do sucesso da investigação científica, devem ser adotados procedimentos razoáveis, no propósito de iluminar e facilitar a fixação de um percurso de conhecimento. Tal percurso não seria o único, mas apenas aquele que foi escolhido por ser considerado o mais apropriado para o objeto em estudo. No âmbito das ciências sociais, tal escolha não deixa de implicar riscos quanto à cientificidade do conhecimento que se pretende produzir. Por isso mesmo, raramente um método é utilizado com absoluta exclusividade, pois o elemento da interdisciplinaridade e as contribuições específicas dos clássicos devem fazer parte, quando possível, de uma saudável síntese procedimental construída à luz da totalidade teórica que recobre as ciências humanas.

\subsection{UM REFERENCIAL}

Nos anos 70, a auspiciosa novidade da reflexão teológica na América Latina foi a incorporação das ciências sociais, que representou uma genuína revolução no método teológico dos cristãos católicos e protestantes. Essa utilização permitiu que muitos movimentos sociais acrescentassem uma fundamentação religiosa às suas ações políticas, bem como igrejas e movimentos eclesiais acrescentassem motivações políticas às suas práticas sociais, sem contar a abertura de um amplo diálogo entre muitos teólogos e cientistas sociais acerca de temas então momentosos.

A Religião emerge como um fenômeno social que se confronta com a pretensão de uma sociedade sob a égide da racionalidade científica. Ao mesmo tempo, as ciências sociais sublinham a função ideológica da Religião, na qualidade de um sistema que integra e agrupa as pessoas, e ainda confere sentido à vida. A Religião, como fruto do consenso social, significa que ela pode se constituir como um fator de coesão entre indivíduos na busca de objetivos comuns e permite a formulação de uma mundividência por intermédio das crenças e dos ritos. A Religião seria uma forma de conhecimento e parte constitutiva da história da humanidade, porquanto se encontra em todas as sociedades conhecidas e assim se apresenta como uma categoria universal. Ademais, as religiões abrangem uma cosmovisão e uma criteriologia dogmática acerca das relações sociais. No tocante ao domínio religioso, aquilo 
que aparenta ser extraordinário e de ordem sobrenatural pode ser um fator explicativo do próprio processo social.

Èmile Durkheim, por exemplo, sustentava que a produção religiosa encontra-se "acima" do crente tomado individualmente, já que o coletivo seria, por excelência, a matriz geradora do sagrado. Para esse pensador, a Religião seria, antes de tudo, a projeção transcendente da organização social.

Durkheim encarava a Religião como possibilidade concreta de consenso, ou seja, um acordo a respeito do sentido dos signos e do sentido do mundo. Para tanto, a Religião, necessariamente, precisa ser uma potência moral capaz de produzir integração social.

Para Max Weber, no entanto, os acontecimentos que integram o social têm origem no indivíduo. Assim, para esse pensador pioneiro, em primeira instância, o pesquisador deveria partir de uma preocupação com os significados subjetivos. A meta seria compreender a ação social por meio dos nexos causais que lhe confeririam sentido. Portanto um mesmo fato poderia ter causas econômicas, políticas e religiosas. Nenhuma dessas causas seria superior às demais em significância. Todas comporiam o conjunto de elementos e aspectos da realidade que se manifestam, necessariamente, nos atos individuais.

Karl Marx, por seu turno, ensinava que as classes dominantes seriam as produtoras e as mantenedoras da ideologia do "sagrado", a fim de introduzir uma perspectiva invertida da realidade social e camuflar a opressão e a espoliação que empreenderiam. Mais tarde, na esteira do próprio método dialético, tornou-se imperativo ponderar que essa "camuflagem" abriria caminho para que as formas religiosas se convertessem também em formas de resistência dos grupos humanos, quer contra a opressão declarada, quer contra a farsa da igualdade social. Desde logo, a questão que emerge, em face da crítica do fenômeno religioso, efetuada por Marx, diz respeito ao fato de que ele participava do ideário cientificista do século XIX que preconizava sem mais o fim da Religião. Em vista disso, ele não teria se dedicado a um estudo mais cuidadoso das religiões como forma de resistência simbólico-cultural. De resto, cabe ressaltar, manteve-se inconclusa a discussão entre os marxistas a respeito das questões em torno da localização da Religião. Entretanto, sem ignorar seu mérito, a crítica de Marx permaneceu por demais circunscrita a um determinado contexto histórico. 
Já no pensamento de Antonio Gramsci (PORTELLI, 1984) - que situava a Religião no plano supraestrutural -, a luta em torno do simbólico e das representações do mundo não se apresenta como um aspecto marginal, mas aparece como parte constitutiva da luta política em favor de mudanças estruturais. E isso, a despeito da heterogeneidade ideológica e social perceptível dentro e dentre as várias manifestações e instituições religiosas. Por isso, Gramsci apreciava a questão religiosa segundo um enfoque que assinalava as singularidades religiosas a cada momento histórico.

Portanto, mesmo em se tratando de uma mundividência, a Religião comporta uma variedade interna que não permite que seja concebida como um conjunto ideológico homogêneo. Todavia, sendo a Religião e o senso comum as formas de representação mais difundidas em qualquer sociedade humana, elas permitem que a sociedade apareça para si mesma como um todo coeso, ou seja, não segmentado pelos sistemas de estratificação; e nisso consiste a função ideológica mais elementar de ambas: produzir um grau considerável de coesão, por intermédio de uma compreensão monolítica da existência social.

A coesão social vê-se reforçada sistematicamente por meio dos ritos. Aparentemente, a finalidade do rito seria ligar o fiel à divindade; entretanto, no plano prático, religa o indivíduo aos seus circunstantes e à sociedade. Ao administrar a relação entre sagrado e profano, a Religião organiza as ambigüidades, as contradições e os conflitos latentes e, dessa maneira, exorciza o caos (ao conferir sentido), restaura as relações desgastadas (por meio da comunhão de ideais) e (re)infunde a esperança utópica (ao rearticular a coesão).

A experiência histórica recente tem indicado que convicções religiosas fundamentaram a participação em lutas sociais e a adesão a projetos de transformação, assim como abriram espaços de coesão para grupos anti-sistêmicos. Apontar essas realidades significa reconhecer os paradoxos contidos na temática. Ademais, faz-se mister reconhecer a autonomia relativa do campo religioso, que o torna muitas vezes apto a cumprir funções que pertenceriam a outros entes sociais.

Tem-se, como exemplo, no caso brasileiro, a Igreja Católica Romana, que exerceu um papel supletivo e mesmo substitutivo nos momentos mais difíceis da repressão durante o regime militar, quando 
organizações sindicais, partidos progressistas e movimentos sociais foram banidos do cenário oficial.

Por último, é oportuno advertir que nem todas as crenças e formas de organização religiosas são permeáveis a propostas transformadoras, quer de si mesmas, quer da sociedade.

Entre as décadas de 1970 e 1990, a auspiciosa novidade da produção teológica na América Latina foi a incorporação das ciências sociais na qualidade de mediação socioanalítica, o que representou uma revolução copernicana no método teológico dos cristãos católicos e protestantes no Continente Latino-Americano e no Terceiro Mundo como um todo. Nessas décadas, foi emblemática a presença dos cristãos e das igrejas na luta contra as violações dos direitos humanos por parte dos regimes de Segurança Nacional; a participação na Revolução Sandinista; e, no Brasil, a atuação em prol da redemocratização e da participação popular.

\section{UM PANORAMA DESSE EIXO TEMÁTICO}

A escolha desse eixo temático não foi aleatória. O Brasil viu-se surpreendido nas eleições presidenciais de 2002 por um fenômeno sem precedentes: a candidatura de um político (Anthony Garotinho) que, ostensivamente, inseria, em sua plataforma e em sua retórica política, princípios e valores produzidos no interior das denominações evangélicas brasileiras. Pode-se dizer que o peso social dos evangélicos havia atingido o seu mais elevado patamar, porquanto estavam a reivindicar, direta ou indiretamente, um presidente da República alinhado às suas doutrinas e princípios éticos. Segundo a lógica das denominações, a presença evangélica no País já é suficientemente significativa para que o mais alto cargo da Nação seja ocupado por um representante desse segmento religioso.

A par disso, o candidato se lançou por uma sigla partidária integrante da esquerda clássica, o Partido Socialista Brasileiro (PSB), contrariando a expectativa de que o voto evangélico tenderia aos candidatos de direita ou de centro. Com isso, o País assistiu a uma aliança curiosa entre vetustos personagens da esquerda marxista e um jovem candidato que mobilizava amplos segmentos evangélicos tidos na conta de conservadores e fundamentalistas. 
Superado o impacto inicial, os analistas passaram a buscar as raízes dessa candidatura, estabelecendo, a priori, alguns elementos: a) a candidatura teve um caráter de teste, porquanto o candidato estaria ciente da impossibilidade de sua vitória; b) a escolha do PSB não seria decisiva, uma vez que a imaturidade e a inconsistência da tradição partidária brasileira é notória e, c) o apoio dos evangélicos à candidatura diria respeito muito mais a pretensões corporativas e imediatistas do que propriamente a um projeto de sociedade acabado.

Porém esses elementos não respondiam a uma indagação recorrente: a participação política, tendo por motivação a adesão e/ ou a filiação religiosa, seria uma alternativa típica da América Latina, esgotados os meios clássicos de mobilização utilizados pela direita e pela esquerda ao longo da história continental? Tal indagação procede, levando-se em conta que os evangélicos tradicionais e pentecostais se mantiveram ostensivamente distantes da política institucional ao longo de quase todo o século XX, ao mesmo tempo em que condenavam enfaticamente a prática política como contrária aos mais elementares princípios morais. Arautos que eram de uma pregação "espiritualizante" tinham as questões políticas como secundárias e mesmo ociosas: em face das coisas do "céu", as coisas do "mundo" se tornavam insignificantes.

Esse panorama só começou a sofrer alterações a partir da década de 1980. Episódios emblemáticos dessa mudança de rumo foram: a primeira eleição de Alberto Fujimori (Peru), a eleição de Rios Montt (Guatemala); enquanto, no Brasil pós-redemocratização, ocorria a articulação da chamada "bancada evangélica". Esses episódios, vistos como indícios, estão diretamente relacionados com o vertiginoso crescimento numérico das denominações evangélicas e pentecostais por toda a América Latina, sobremodo após a década de 1960. A partir de um determinado momento, na maioria dos países da América Latina, os candidatos a cargos eletivos não podiam mais ignorar um segmento social com comprovada capacidade de mobilização e organização.

Ao longo de duas décadas (setenta e oitenta) o cristianismo continental sofreu mais mudanças e abalos do que em todos os seus cinco séculos de permanência. As relações com as massas e com as elites, a organização interna das Igrejas, o discurso religioso, o pensamento teológico, as atividades catequéticas, pastorais e sociais, bem como as posturas políticas sofreram mudanças substanciais que iriam reconfi- 
gurar o campo religioso e traçar os contornos do cenário atual. Apenas refazendo essa trajetória e relendo os fatos religiosos desse período, é possível arriscar uma interpretação confiável do quadro atual. Evidentemente, tais abalos corresponderam, no todo ou em parte, aos conflitos de interesses das potências nascidas das cinzas da Segunda Guerra Mundial, à bipolaridade geopolítica consubstanciada na Guerra Fria e à consolidação dos EUA como potência hegemônica.

A par disso, crescia nos Estados Unidos o neoconservadorismo que fazia um diagnóstico pessimista quanto à legitimidade dos regimes democráticos ocidentais, ou seja, a existência de uma crise moral e cultural em face da expansão de uma "cultura adversária". Segundo a perspectiva dos neoconservadores, o cerne da cultura norte-americana havia sido danificado pela crítica "irresponsável" de intelectuais liberais e secularizados, supostamente desconectados dos valores das maiorias. Dessa forma, ainda segundo o pensamento neoconservador, tornou-se imperativa uma luta ideológica sem quartel, no plano da sociedade civil, para restaurar o senso de autoridade; assim como uma luta da mesma natureza voltada para o exterior, no intuito de combater a hostilidade generalizada contra os interesses norte-americanos.

Na América do Sul, na esteira dos regimes de Segurança Nacional, os setores ultraconservadores norte-americanos exerceram uma influência considerável e patrocinaram de todos os modos a expansão numérica e patrimonial de evangélicos; sobremodo por meio das chamadas Missões de Fé e por uma rede de organizações conhecidas como paraeclesiásticas. A respeito de missões estrangeiras nesse período, informa-nos Davi Stoll (1990, p. 91):

A maioria dos homens e mulheres que saíam para o estrangeiro eram especialistas - pilotos, semeadores de igrejas, lingüistas, professores, radiodifusores. Traduziam a Bíblia, produziam discos, fitas e programas de televisão no idioma nativo, fundavam institutos bíblicos e estações de rádio, administravam cursos por correspondência, organizavam inumeráveis conferências mundiais e tratavam de saturar países inteiros com sua mensagem. Existiam missões médicas, missões para as universidades, incluindo barcos carregados com centenas de jovens missionários navegando pelos mares - o Doulos 
e Logos da Operação Mobilização, o Anastasia e o Good Samaritan da Juventude com uma Missão. Em montanhas e selvas remotas, empresas aéreas, como a Asas do Socorro (Missionary Aviation Fellowship), mantinham linhas de abastecimento, transportavam pacientes e médicos e forneciam ajuda em desastres. Apoiando-as se encontravam as organizações de ajuda e desenvolvimento - World Vision (Visão Mundial), World Relief (Auxílio Mundial), World Concern (Preocupação Mundial), World Neighbors (Vizinhos Mundiais) (tradução nossa). ${ }^{4}$

No contexto brasileiro, à semelhança do que ocorria nos Estados Unidos, as denominações do protestantismo clássico começaram a vivenciar um processo de decadência a partir da década de cinqüenta, cedendo espaço para novas propostas religiosas que aportaram, no Brasil, caminhos até então inexplorados. As Missões de Fé e as paraeclesiásticas produziram um método inteligente de investir recursos humanos, materiais e financeiros em instâncias estratégicas das denominações instaladas, tais como a educação teológica, a educação religiosa e o evangelismo.

Além da preocupação de ampliar o número de adeptos, essa modalidade missionária representava uma contrapartida aos empenhos libertários e progressistas de parte do catolicismo e do protestantismo no Continente, empenhos estes que tiveram como símbolo a denominada Teologia da Libertação.

Essa corrente, que tinha na Teologia da Libertação seu referencial teórico, as Comunidades Eclesiais de Base (Cebs) como espaço pastoral e de espiritualidade, os movimentos sociais e populares como espaço de atuação política, as organizações progressistas da sociedade como aliados, a indignação ética como referencial ideológico e uma sociedade igualitária como horizonte, e que envolveu católicos e protestantes por todo o Continente, teve vida curta.

O pontificado de João Paulo II, com suas alianças com o capitalismo hegemômico, sua preferência pelos movimentos (Renovação carismática, Opus Dei, Cavaleiros de Cristo, etc.), em detrimento das pastorais, por intermédio de várias diretrizes, encaminhamentos, expurgos e medidas "administrativas" da Cúria, soube dar cabo das pretensões do catolicismo progressista do Terceiro Mundo. Por seu 
turno, as denominações protestantes preferiram o neoconfessionalismo, o neoconservadorismo e não resistiram ao mimetismo em face do formidável crescimento numérico e patrimonial dos pentecostais.

Voltando às Missões de Fé, essas missões e organizações, "transconfessionais" por definição, além do proselitismo puro e simples, implementaram projetos assistenciais e culturais, no bojo dos quais se operava uma articulação entre atitude sectária, pensamento fundamentalista e anticomunismo ferrenho.

Não divulgavam amplamente seus trabalhos, preferindo agir discretamente protegidas pelas estruturas das próprias denominações instaladas, o que lhes conferia legitimidade e seriedade, e alcançavam apenas um público selecionado (jovens, de preferência). A eficiência dessa estratégia era demonstrada pela qualidade das publicações que editavam e distribuíam pelos seus programas de formação de quadros, do tipo de eventos que realizavam e auspiciavam e pelo apoio discreto e sistemático que ofereciam às igrejas. Na verdade, buscavam formar uma mentalidade, com resultados previstos de longo prazo.

Com essa postura, ao invés de se apresentarem como autônomos, foram acumulando prestígio e inspirando confiança nas burocracias dirigentes das denominações históricas que, paulatinamente, foram entregando a essas missões e organizações o controle de boa parte da formação dos jovens, quer no plano da educação teológica, quer no da educação religiosa. Assim, as Missões de Fé não só se tornaram as virtuais controladoras do discurso religioso e teológico, como obtiveram livre trânsito entre as igrejas para disseminar conteúdos ideológicos. Para tanto, movimentaram milhares de dólares.

Nos Estados Unidos, no final da década de 70, mesmo os segmentos evangélicos conservadores e pentecostais se sentiram constrangidos por não terem apoiado mais explicitamente a campanha pelos direitos civis e a resistência contra a guerra do Vietnã. O chamado caso Watergate abalou as estruturas, e a questão das armas nucleares adquiriu ainda mais relevância, num ambiente no qual o Estado e seus dirigentes perderam prestígio; afinal, eles tinham nas mãos a chave da Caixa de Pandora. A despeito do fundamentalismo atávico, os temas do militarismo e da participação social e política ingressaram na agenda das igrejas e movimentos conservadores, pelo menos até a eleição de Ronald Reagan. 
No entanto o que captava efetivamente a atenção dos evangélicos conservadores norte-americanos eram os pretensos prejuízos e virtuais ameaças ao assim chamado american way of life. O ensino livre da teoria evolucionista nas escolas públicas; a decisão de suprimir as preces antes das aulas nas mesmas escolas; a legalização do aborto; a igualdade para as mulheres e os direitos para homossexuais seriam assuntos muito mais preocupantes que as guerras, as armas nucleares ou a pobreza, porquanto os fazia se sentirem ameaçados em sua segurança objetiva e subjetiva. Outrossim, a administração Carter, com sua ênfase nos Direitos Humanos, havia sido uma decepção, mesmo sendo esse presidente um típico representante dos setores evangélicos tradicionais. Com isso multidões de evangélicos se aliaram à ultradireita do Partido Republicano, e os chamados televangelistas tornaram-se os arautos da nova direita política e religiosa.

A disposição dos adeptos da candidatura Reagan era proceder a uma associação entre um sentimento religioso conservador e uma ação política também conservadora, a partir de uma argumentação específica que mesclava fundamentalismo com religião civil. Não poderia ser diferente, pois, paulatinamente, o discurso teológico das igrejas tradicionais norte-americanas deixou de ser legitimador dos interesses dominantes. Estes careciam de um discurso bíblico e religioso que favorecesse a adaptação das massas naquele estágio do capitalismo transnacionalizado, sobre o qual os Estados Unidos pretendiam exercer uma liderança plena e inconteste. Com a civil religion combalida, o fundamentalismo evangélico passou a ser novamente atraente para as elites do poder. Portanto, por serem interdependentes, fundamentalismo e o neoconservadorismo avançaram juntos, secundados pelas classes dominantes e dirigentes.

A direita religiosa, com suas múltiplas alianças, conexões, suporte editorial e de mídia, e um grande contingente de simpatizantes dentro e fora dos EUA, atuou como instrumento na complexa estratégia neoconservadora de luta ideológica, no plano nacional (propostas alternativas no âmbito da sociedade civil norte-americana) e no internacional (URSS, Cuba e Terceiro Mundo). Partiram do pressuposto de que o campo religioso se afigurava como um espaço decisivo de ação, porquanto a luta ideológica por eles implementada perseguia a obtenção de uma hegemonia, ou seja, a construção de um consenso 
ideológico entre as organizações, os movimentos e as instituições eclesiais e eclesiásticas.

Alguns anos mais tarde, os efeitos de toda essa atuação, entre tantos outros, seria a participação política explícita e organizada dos evangélicos fundamentalistas, consubstanciada na candidatura de Pat Robertson à Presidência da República pelo partido Republicano, assim como na formação da Christian Coalition, movimento por meio do qual a direita religiosa participou e participa diretamente na política partidária e estatal, organizando lobbies, realizando manifestações contra ou a favor de determinadas políticas públicas e marcando presença nas convenções partidárias. Esse modelo de participação evangélica na política vem sendo ensaiado no Brasil desde a redemocratização e viria a ter resultados significativos.

\section{EXPANSIONISMO EVANGÉLICO E SOCIEDADE CIVIL}

Segundo alguns historiadores da religião, o crescimento evangélico na América Latina teria acontecido por meio de sucessivos empenhos missionários, por eles denominados "ondas de evangelismo". A primeira teria ocorrido ao longo do século XIX, por iniciativa das denominações históricas da América do Norte. Essas missões tinham como ideário a liberdade religiosa contra o predomínio católico romano, além de provocar conversões e implantar templos, construir escolas e hospitais. Em uma ou duas gerações, os convertidos já teriam perdido o fervor proselitista.

A segunda onda teria como atores principais os fundamentalistas, com seus movimentos e organizações. Após a Segunda Guerra, essa modalidade missionária já havia substituído as missões clássicas, porém, ambas as alternativas não obtiveram o sucesso desejado. Já na década de 1960, haviam sido superadas pelo pentecostalismo, cujo controle estava a cabo de lideranças autóctones, insatisfeitas com o autoritarismo das agências estrangeiras, que passaram à condição de patrocinadoras (financeiras, materiais e ideológicas) eventuais, que agiam com maior ou menor discrição.

Movidos pelo receio de uma outra revolução do tipo cubano, muitos evangélicos avaliaram positivamente o advento dos regimes de Segurança Nacional, daí o apoio explícito das igrejas pentecostais aos 
golpes militares no Brasil, no Chile e na Guatemala, e a notória militância contra o sandinismo. Apenas minorias mais ativas denunciaram, juntamente com grupos católicos, as violações dos direitos humanos cometidas pelos regimes militares; enquanto a grande maioria preferiu adotar uma atitude condescendente em nome do combate ao comunismo. Quando importantes prelados da hierarquia católica se recusaram a abençoar os regimes de exceção por todo o Continente, lideranças evangélicas preeminentes estavam prontas para conferir a esses regimes uma marca de legitimidade religiosa e política. Em contrapartida, os governos militares concederam plena liberdade para que os evangélicos, em geral, e os pentecostais em particular, propagassem sua versão do cristianismo, sobretudo por meio do livre acesso ao rádio e à televisão. Com efeito, nesse período, a história do propalado absenteísmo político dos evangélicos começa a experimentar o seu ocaso.

Ainda no tocante à participação política dos evangélicos, é oportuno ponderar a respeito de um fator estrutural. $\mathrm{O}$ absenteísmo político dos evangélicos convergiu com a predominância de duas motivações, em dois momentos históricos distintos, a saber: a) aproximadamente, de meados do século XIX até a Segunda Guerra: exclusividade para os esforços destinados à expansão do número de adeptos, assim como na expansão financeira e patrimonial, em oposição ao catolicismo dominante; b) após a Segunda Guerra, com o total alinhamento aos cânones da Guerra Fria, pois, muito embora não tivessem envolvimento político explícito, as denominações evangélicas exerciam um rigoroso controle social sobre as inclinações ideológicas dos seus adeptos.

Assim sendo, a situação só foi se tornando mais favorável à participação política na proporção em que foi arrefecendo a bipolarização ideológica em favor do capitalismo, até o total desmoronamento do socialismo soviético, no apagar das luzes da década de 1980. O fim da Guerra Fria e a implantação da total hegemonia da alternativa capitalista de mercado tiveram como um dos seus desdobramentos a possibilidade, cada vez mais prestigiada, de uma nova forma de ação política - a afirmação da cidadania por intermédio do reforço e da ampliação dos domínios da chamada sociedade civil, em particular no âmbito do Terceiro Mundo.

A sociedade civil como uma categoria e também um símbolo, não está isenta de definições ambíguas, pois não se trata de um conceito 
unívoco. Ademais, a sociedade civil comporta um caráter simbólico, porquanto se trata de um espaço social construído sobre pluralidades e contradições, tensões e diversidades.

Evidentemente, tal conceito significa coisas distintas para pessoas e grupos distintos. Em diferentes contextos, tem recebido diferentes interpretações nos níveis teórico e prático, por parte das várias tradições e correntes políticas. Contudo, no atual momento histórico de transição, esse conceito tem despertado a atenção de todos os setores da sociedade, desde os grupos de base até o Banco Mundial. Considerá-lo como uma concepção estritamente ocidental não diminui sua relevância e pertinência. Por outro lado, esse conceito não deve ser utilizado como uma "camisa-de-força", mas apenas como um elemento que soma no enfrentamento do desafio para afirmar a vida civil para além da crise atual das grandes instituições sociais e do Estado.

A título de ilustração, vale apreciar o tema em relação aos Estados Unidos. Esse país, onde nunca foi elaborada uma noção coerente de Estado, tem sido reconhecido mundialmente como um modelo de sociedade civil. Os valores norte-americanos, baseados na adesão a um conjunto de crenças, têm adquirido um caráter messiânico, uma espécie de referência da cidadania universal. Por isso mesmo, do ponto de vista ideológico, a noção de sociedade civil tem sido muitas vezes considerada um "americanismo".

Vale acrescentar que a sociedade civil organizada a partir da adesão a um conjunto de crenças e valores respectivos, configura a denominada "religião civil", sendo esta, por definição, um casamento entre política e religião. Como substrato dessa religião civi,l encontra-se o conceito de "Destino Manifesto", cujo conteúdo consiste na crença de que, a cada período histórico deve existir uma civilização dirigente, com um papel protagônico, e isso segundo um movimento cíclico e inexorável, porque advém diretamente da "providência divina".

Os movimentos neoconservadores, bastante ativos nos anos 80, engendraram a idéia do "capitalismo democrático" projetada para o plano mundial. Por esse motivo, esses movimentos enfatizaram a sociedade civil como um instrumento de promoção do chamado "conservadorismo das massas". Durante a administração Reagan, esse conservadorismo teria sido a inspiração para as campanhas em favor de causas reacionárias no âmbito das associações, grupos, movimentos, 
organizações e igrejas. Em virtude da supremacia ideológica, cultural e política norte-americana, nem é preciso dizer que a América Latina sofreu influência dessa movimentação.

Na esteira desse fenômeno ideológico, foi concebido o projeto de "democracia global" - um componente muito importante da nova ordem internacional implantada após a queda do muro de Berlim - anunciado nos Estados Unidos como uma atualização do Destino Manifesto. A democracia global seria definida como uma expansão nada menos que planetária da liberdade política e econômica, segundo o prisma da lógica neoliberal. De acordo com essa mesma lógica, os alicerces da democracia seriam o mercado e o privatismo. E essa tem sido a lógica dos chamados "falcões" que assessoram o presidente George W. Bush em sua política externa.

No Continente Latino-Americano, a concepção de sociedade civil tem estado intimamente vinculada aos temas do desenvolvimento e da democracia. Para as esquerdas, a temática das funções do Estado tem sido a referência principal no tratamento da questão da sociedade civil. Porém, apenas após a Segunda Guerra, é que começa a surgir, no panorama teórico das esquerdas, a possibilidade de um entrelaçamento entre as instâncias estatais e os movimentos sociais. No entanto, tal experiência foi abortada em virtude da implantação dos regimes de Segurança Nacional. Segundo a perspectiva da esquerda, os regimes militares reorganizaram, a seu modo, o velho e conhecido "loteamento" do Estado entre as elites.

Na atualidade, entre os povos e países que se situam na periferia do capitalismo, o que se verifica é um considerável número de decisões políticas e econômicas - antes sob a responsabilidade dos Estados nacionais - transferidas para organismos como o FMI, o Banco Mundial e mesmo o Departamento de Estado dos EUA, e isso no bojo de um processo denominado "associação transnacionalizada". Assim, podese asseverar que o projeto neoliberal não pretendia apenas erradicar a função benfeitora do Estado, mas alterar sua própria natureza, ao alterar o sentido clássico do que se entende por soberania nacional.

Essa associação transnacionalizada determina uma série de novas funções para o Estado, a saber: 
a) facilitar a dependência em relação ao sistema monetário mundial;

b) assumir responsabilidades no desmantelamento das forças organizadas da sociedade civil e transferir aos setores privados e às ONGs o enfrentamento de necessidades e demandas sociais importantes (privatização da pobreza);

c) promover a aceitação da "sociedade dual", ou seja, uma minoria privilegiada em frente a uma vasta maioria carente dos direitos fundamentais.

Em decorrência disso, muitos passaram a enfatizar a função da sociedade civil segundo uma perspectiva unilateral. Um dos sintomas dessa ênfase unilateralista seria a crescente aceitação da economia informal como uma solução permanente. Por meio dela, a sociedade civil buscaria responder aos problemas da marginalização e da exclusão. Nesse quadro, as atividades econômicas procedentes de iniciativas privadas de pequena escala seriam a única alternativa. No entanto, essa alternativa comporta sérias antinomias, tais como: a) seria uma modalidade de cooptação por parte das políticas de reajuste, que transferem suas responsabilidades de produtora de custo social para os setores desfavorecidos da sociedade; b) a substituição gradativa de assalariados por trabalhadores supostamente autônomos seria apenas um adiamento dos problemas sociais e econômicos resultantes das políticas de reajuste; c) transformar a massa de trabalhadores pobres em (micro)comerciantes e em prestadores de serviços periféricos pode constituir-se num fator de desmobilização das organizações populares; d) o fracasso generalizado das alternativas no âmbito informal da economia pode conduzir ao caos social.

Muitos podem considerar que as massas empobrecidas, organizadas por meio da economia informal, como se verifica em muitos países do Continente, poderiam vir a se converter numa força política que iria inventar caminhos também informais na busca pelo poder. Contudo, o sistema introduziu uma distinção: a propalada transnacionalização da democracia, perfeitamente tolerada e mesmo incentivada pelos poderes dominantes, estabeleceu uma diferença qualitativa entre a vitória eleitoral e a tomada real do poder. Assim, o nú- 
cleo intocável do poder real reside no sistema econômico-financeiro, ao passo que as instituições políticas, incluindo o processo eleitoral, tornar-se-iam apenas uma espécie de alegoria do poder. Esse é um dos dilemas em que foi mergulhado o governo Lula, mesmo após uma esmagadora vitória nas urnas.

Nesta altura, vale advertir que a sociedade civil não pode ser concebida como uma panacéia para uso dos intelectuais, nem uma solução fácil para os que insistem no ativismo social. Antes, ela pode ser definida como um horizonte ético, um sonho centrado em valores orientados para a utopia de uma nova sociedade igualitária e participativa. Trata-se ainda de um chamado à imaginação criativa na busca de alternativas sociais. Quando a esperança se encontra fragilizada, como na atual transição civilizatória, e persiste a carência de uma alternativa coerente e exeqüível em curto prazo, um desafio seria entender essa debilidade como uma possibilidade em potencial.

$\mathrm{Na}$ atual conjuntura internacional, faz-se necessário reconhecer que se encontra em curso uma espécie de "nudez ideológica", sobremodo no que diz respeito à integração entre Sociedade Civil e Estado. As atuais interpretações não podem mais contar com a noção de lei natural da Idade Média, nem com a exacerbação da Razão, como no Iluminismo; nem com o controle supremo do Estado ao modo das tradições hegeliana e marxista; nem na auto-regulação dos interesses individuais, como na economia de mercado clássica. Isso fica ainda mais agravado pelo êxito do sistema em manipular muitos dos movimentos sociais existentes.

A despeito de tudo, porém, é visível que a sociedade civil mundial encontra-se em movimento. Nela pode ser percebida a configuração de novos tipos de organizações políticas. Tratar-se-ia de um novo poder emergente, nascido no calor da resistência e da sobrevivência em meio às adversidades do cotidiano. São ainda formas embrionárias, no entanto, caracterizadas sobremaneira pela solidariedade e pelo voluntariado, bem como pela resistência ante a fragmentação e a desintegração, bem como a afirmação cultural perante as tentativas constantes de homogeneização e de imobilização, a partir de uma nova criteriologia de organização e de uma racionalidade alternativa. É oportuno assinalar que a expressão mais visível dessa emergência seria o Fórum Social Mundial. 
Vale advertir que, por vezes, o conceito de sociedade civil é tão amplo que permite todas as interpretações e inclui ambigüidades. Quando os organismos financeiros internacionais usam a expressão, por exemplo, trata-se de algo muito diferente de quando é utilizado no contexto do Fórum Social Mundial. Desde logo, é preciso reconhecer a sociedade civil como um espaço de lutas sociais onde são formuladas propostas coletivas consistentes e fundamentais. Portanto, a sociedade civil seria um espaço social no qual diversos grupos são mobilizados e organizados para confrontar, encaminhar e mesmo solucionar problemas coletivos que decorrem do novo panorama estrutural e conjuntural. Dito de outra maneira, a sociedade civil pode ser compreendida como uma estratégia de transformação social, dotada de uma ênfase na formulação de um projeto de sociedade a partir de suas bases.

A ênfase na busca por alternativas locais, em face do ocaso das ideologias totalizantes, não significa simplesmente adotar uma preferência pelas utopias de curto alcance. Articulações de pequena escala podem ser frágeis o suficiente para não sobreviverem aos contra-ataques dos poderes hegemônicos. Os microprojetos não podem ignorar o caráter impositivo dos sistemas globalizados. O modelo neoliberal confina o político ao cuidado dos setores vulneráveis da sociedade, justamente para que não avancem nem medrem quaisquer projetos alternativos e nem causem impacto às propostas de transformação de cunho abrangente. Do mesmo modo, nenhuma proposta alternativa ou experiência social inédita pode olvidar a necessidade de contribuir no sentido de mudanças estruturais, ou seja, transformações ostensivas no sistema global de dominação. Portanto, no debate acerca do papel da sociedade civil, a temática em torno da dialética entre o local e o global se mostra imprescindível.

\section{O CASO DAS ONGS}

Na ótica das elites dominantes, a sociedade civil seria o lugar do desenvolvimento das potencialidades e o espaço do exercício das liberdades, para os indivíduos. Dentre essas liberdades, destaca-se a do empreendimento empresarial, entendida como a matriz de todas as demais. Portanto, a empresa seria o eixo da sociedade civil. As empresas devem ser articuladas as instituições de cunho ideológico, com suas atividades 
precípuas de reprodução social (as escolas, os meios de comunicação e as agremiações religiosas) e as organizações voluntárias destinadas a suprir as carências produzidas seletivamente pelo próprio sistema. Nesse cenário, o papel do Estado seria limitado a implantar normas jurídicas destinadas a garantir a propriedade privada, o livre exercício empresarial, assegurar o bom funcionamento da reprodução social por intermédio dos serviços essenciais e prover a segurança pública.

Dessa lógica sistêmica implacável faz parte a economia de mercado como um dado "natural" e não como uma relação socialmente construída. Ademais, segundo essa concepção, o mercado seria o regulador supremo das interações humanas. Ainda conforme essa lógica, reforçar a sociedade civil significa dinamizar os atores sociais empreendedores, reduzir o espaço estatal e reproduzir a dominação. Disso resulta uma estratégia correspondente que implica a valorização da rede de organizações voluntárias privadas. Isso permite a canalização institucional das demandas das massas empobrecidas, ao mesmo tempo em que fragmenta suas reivindicações. Assim fica bastante fácil cooptar organizações religiosas (ou não) imbuídas do propósito de atenuar os efeitos da pobreza.

Tal cooptação se torna facilitada quando se sustenta que a sociedade civil seria composta pelos grupos representados pelas ONGs e por organizações não lucrativas, bem como pelos movimentos voluntários. Tratar-se-ia do assim chamado Terceiro Setor, autônomo e supostamente aparelhado para manter uma postura anti-sistêmica conseqüente. Em resumo, seriam as organizações e redes de organizações que desejam o bem comum e desejam mudar o curso dos acontecimentos, num panorama de injustiça e exclusão. No entanto, muito embora a estratégia delas inclua a denúncia das mazelas do sistema, não tem sido capaz de atingir o cerne de sua lógica, o que as coloca à mercê de manipulações, sobretudo daquelas destinadas a esvaziar o papel e o sentido do Estado.

Nesta altura, é oportuno recordar que o espaço público tem sido forjado pelo mercado. As elites mundiais têm utilizado os Estados nacionais não para a redistribuição da riqueza, nem para a proteção dos desfavorecidos, mas, sim, para exercer controle sobre as maiorias e pô-las a serviço dos interesses prioritários do mercado. Para tanto, os expedientes são os mais variados e vão desde a política monetária 
e os tratados comerciais até o controle das ONGs, passando pelas privatizações e "adequações" da ordem jurídica. Desse modo, o mercado comanda as ações tanto no plano nacional quanto no internacional (como bem evidenciam as crises cíclicas da ONU).

É oportuno acrescentar que o pensamento denominado pósmoderno sente-se bastante à vontade nesse cenário, pois afirma o desaparecimento das "grandes narrativas", ou seja, o fim dos sistemas, das grandes estruturas e das interpretações de conjunto. Tudo isso seria substituído pelas realizações imediatas, a intervenção direta do indivíduo sobre o seu ambiente histórico e uma interpretação que privilegia as iniciativas particulares e as utopias de curto alcance. Em reação a uma modernidade "prometeica" e seu discurso totalizante, o indivíduo é impelido para uma leitura fragmentada da realidade que apresenta a sociedade civil como uma espécie de simples adição de organizações e movimentos.

As mudanças tecnológicas estão a causar perplexidade, tanto pela sua celeridade, quanto pela intensidade e volume das inovações. No campo das telecomunicações, destacam-se as redes mundiais de televisão, que promovem um acesso massivo e inédito à informação, o que acaba por reduzir o controle por parte das elites do poder, muito embora a "filtragem", a autocensura nas redações e os expedientes das comunidades de inteligência colaborem no sentido de que tal controle persista, ainda que arrefecido. Por outro lado, grupos, movimentos antisistêmicos e mesmo nações periféricas têm utilizado os meios eletrônicos de comunicação para divulgar seus pontos de vista e ainda fazer circular contra-informação e contra-ideologia, como ocorreu em relação ao Acordo Multilateral de Investimentos (AMI) ${ }^{5}$ Esse acordo, que estava sendo celebrado secretamente, uma vez denunciado por uma organização não-governamental, teve sua continuidade interrompida.

\section{6 À GUISA DE CONCLUSÃO}

Retomando o argumento de que jamais houve separação nítida entre Religião e Política, no quadro atual de transição civilizatória e de implantação de uma nova ordem internacional, assiste-se a Igrejas ou organizações representativas 
[...] que vão a público, mantêm interlocução com as autoridades civis e políticas, publicam manifestos, apóiam abertamente candidatos a cargos eletivos, organizam manifestações de rua. O Poder Executivo conclama organismos religiosos a atuarem diretamente, de forma subsidiária ou substitutiva, na implementação de programas sociais em áreas como educação, saúde, violência ou geração de emprego e renda (em moldes que vão das parcerias às políticas de desinvestimento estatal na área social, que transfere a organismos privados a oferta e gestão de serviços de interesse público). Organizações da sociedade civil crescentemente se auto-definem como um 'terceiro setor', público e não-estatal, com pretensões de interferir diretamente nas decisões políticas e nas práticas de mercado, e contam os organismos religiosos entre os que compõem este setor (BURITY, 2001, p. 4).

Vale a pena retomar aqui o exemplo do candidato Anthony Garotinho. Âs portas das novas eleições presidenciais, Garotinho já se encontra na quarta sigla partidária em sua carreira política, mas continua insistindo nos princípios religiosos de sua candidatura e continua buscando ampliar suas bases eleitorais no campo evangélico. Por seu turno, muitos dos integrantes da ruidosa "bancada evangélica" encontram-se envolvidos nos mais notórios escândalos de corrupção, o que evidencia seu descompromisso com a ética na política, e mesmo sua infidelidade com as diretrizes morais das agremiações religiosas que ostentam representar. Com razoável brandura, Joanildo Burity (2006, p. 9) explica:

O pluralismo facilita o acesso à esfera política e isto, em circunstâncias de forte peso da religião na vida cotidiana, se expressa em termos de aumento na participação política (representação e presença na tomada de decisões) por parte de indivíduos e grupos/movimentos religiosos; tal participação, contudo, na medida em que incorpora atores com pequena ou nenhuma experiência prévia de exposição à esfera política, corre sempre o risco de importar para o campo político formas de intransigência e imposição muito difundidas no campo religioso, ou de se perder no labirinto das redes clientelistas ou corporativistas da política contemporânea. 
Pelo que tudo indica, a participação política, a partir de fidelidades religiosas, não se prende propriamente a uma construção ético-teológica ou a um projeto alternativo de sociedade construído a partir do locus eclesiástico, mas, sim, é uma decorrência do fato de que tanto a religião quanto a política se encontram desconectados de "territórios" específicos e se deslocam com certa desenvoltura em todos os espaços sociais.

Portanto não se trata propriamente da escolha efetiva da vertente religiosa como uma alavanca para a participação; a questão reside em que nem a política nem a religião são mais as mesmas, ou seja, não se estribam mais nos mesmos pressupostos organizativos, ideológicos ou mesmo identitários, conforme consagrados pela modernidade, e que se liquefazem no cenário pós-moderno consumista; como tão bem assinala Richard Sennett (2006, p. 125): “[...] será que as pessoas realmente vão fazer compras de políticos como fazem compras de roupas? Em vez de considerar o cidadão apenas como um eleitor indignado, poderíamos encará-lo como um consumidor de política, pressionado a comprar".

Na proporção em que a política tradicional (a par de tantas outras tradições) perde prestígio, o pragmatismo exacerbado transforma candidatos identificados com determinadas confissões, denominações e movimentos religiosos apenas e tão-somente em representantes credenciados dessas organizações para a obtenção de vantagens patrimoniais, benesses estatais e prestígio social, pois que não se trata propriamente de "participação" nos termos inicialmente definidos, mas de uma modalidade de "participação" que consiste numa incursão corporativista no patamar estatal. Muito embora haja um discurso elaborado de defesa da ética na política, este tem funcionado apenas no âmbito retórico. ${ }^{6}$

No Brasil de hoje, acentuam-se as relações entre Religião e Política, tendo como pano de fundo as formas de intervenção da nova ordem internacional sobre a realidade brasileira, sem deixar de considerar as idiossincrasias da cultura nacional, na qual a Religião e a religiosidade sempre tiveram papel de destaque. De semelhante modo, não se deve descurar que a participação política, pela via religiosa, inclui boa parte das massas desfavorecidas e mesmo das classes intermediárias, que rejeitavam ou não tinham acesso às alternativas até então existentes. Contudo, a qualidade dessa participação não pode ser peremptoriamente classificada como um salto de qualidade democrático, ou ainda como um 
avanço da cultura política, em face dos empecilhos monumentais criados pela ordem neoliberal e seus poderosos mecanismos de alienação.

Ademais, pela vez primeira, assiste-se à emergência de um sistema econômico que, ao contrário de todos os seus antecessores remotos e recentes na história da humanidade, dispensa a legitimação religiosa. Tal condição só se torna possível porque, de modo velado ou explícito, o sistema reivindica um tipo de "sacralidade" intrínseca que o coloca para além das religiões organizadas, bem como da religiosidade individual, pois, ao determinar a impossibilidade de qualquer alternativa a ele, coloca-se como uma divindade a quem todos devem obediência e veneração, independentemente do credo religioso de que porventura são professos.

À semelhança do período no qual o Império Romano tolerava todas as religiões, desde que reconhecessem a divindade do imperador, vive-se um processo em que a mescla entre Religião e Política não gera os efeitos esperados em períodos históricos anteriores, porquanto ambas as instâncias se encontrariam submetidas à "adoração" do deus-mercado. Vale ressaltar, por derradeiro, que a identificação, a compreensão e a interpretação desse fenômeno inédito e inusitado se configuram como um dos grandes desafios para uma nova e genuína experiência democrática em nossas latitudes que conclamam

[...] a obrigatoriedade de medidas de efetividade éticoculturais que abram o espaço para um processo pedagógico revolucionário, gerador de um 'novo sujeito histórico' emancipado e de uma nova consciência crítico-criadora. Este mesmo processo libertador propiciará condições para o exercício pleno da cidadania, e de uma maior e mais democrática participação comunitária na tomada de decisões (WOLKMER, 1994, p. 66).

\section{REFERÊNCIAS}

BURITY, Joanildo. Religião e política na fronteira: desinstitucionalização e deslocamento numa relação historicamente polêmica. Revista de Estudos da Religião, São Paulo, n. 4, p 1-15, 2001. 
DUPAS, Gilberto. Ética e poder na sociedade da informação: de como a autonomia das novas tecnologias obriga a rever o mito do progresso. São Paulo: UNESP, 2001

DURKHEIM, Èmile. As formas elementares da vida religiosa. Rio de Janeiro: Martins Fontes, 1996

As regras do método sociológico. Rio de Janeiro: Martins Fontes, 1995.

FERNANDES, Florestan (Org.). K. Marx, F. Engels. São Paulo: Ática, 1983.

PORTELLI, Hugues. Gramsci e a questão religiosa. São Paulo: Paulinas, 1984.

SENNETT, Richard. A cultura do novo capitalismo. Rio de Janeiro: Record, 2006.

STOLL, David. America Latina se vuelve protestante? Las políticas del crecimiento evangélico. Cayambe, Ecuador: Abya-Yala, 1990.

WEBER, Max. Economia e sociedade: fundamentos da sociologia compreensiva. Brasília: UnB; São Paulo: Imprensa Oficial do Estado de São Paulo, 1999. v. 1.

. Metodologia das ciências sociais. São Paulo: Cortez; Campinas: UNICAMP, 1992.

WOLKMER, Antonio Carlos. O terceiro mundo e a nova ordem internacional. 2. ed. São Paulo: Ática, 1994.

\section{NOTAS}

1 Doutor em Ciências Sociais; professor na graduação de Direito e no Programa de Pós-Graduação Stricto Sensu em Direitos e Garantias Fundamentais da FDV.

2 Em 2004, a ONU, por intermédio do Programa das Nações Unidas Para o Desenvolvimento (PNUD), realizou uma pesquisa em 18 países da América Latina, com cerca de 19 mil pessoas, concluindo que 56,3\% dos entrevistados entendem que o desenvolvimento econômico é mais importante que a democracia.

3 Fetiche seria uma relação social e a concepção a ela correspondente, que atribui às coisas qualidades especificamente sociais e toma por algo natural as propriedades criadas pela cultura humana. Assim sendo, os resultados 
da atividade humana recebem uma independência "mística" e um poder sobre os indivíduos.

4 Tradução livre do original: “La mayoría de hombres y mujeres que salían al extranjero eran especialistas - pilotos, sembradores de iglesias, lingüistas, profesores, radiodifusores. Traducían la Biblia, producían discos, cintas y programas de televisión en idioma nativo, fundaban institutos bíblicos y estaciones de radio, administraban cursos por correspondencia, organizaban innumerables conferencia mundiales y trataban de saturar países enteros con su mensaje. Existían misiones médicas, misiones para las universidades, incluso barcos cargados con cientos de jóvenes misioneros arando en los mares - el Doulos y Logos de la Operación Movilización, el Anastasia y Good Samaritan de la Juventud con una Misión. En montañas y selvas remotas, empresas aéreas como Alas de Socorro (Missionary Aviation Fellowship) mantenía líneas de abastecimiento, evacuaba a pacientes médicos y proporcionaba ayuda en los desastres. Apoyándolos se encontraban las organizaciones de ayuda y desarrollo - World Vision (Visión Mundial), World Relief (Auxílio Mundial), World Concern (Preocupación Mundial), World Neighbors (Vecinos Mundiales)".

5 Tal acordo começou a ser engendrado em 1995, por iniciativa da Organização de Cooperação Para o Desenvolvimento Econômico (OCDE), que inclui 29 países, com vistas a uma liberação mundial da economia, ou seja, a eliminação quase absoluta das barreiras aos investimentos externos, conferindo aos investidores internacionais condições eqüitativas em qualquer país onde decidissem alocar seus investimentos. Criada em 1961, a OCDE é um fórum para a coordenação política, econômica e social dos Paísesmembros. Juntos, eles produzem dois terços de todos os bens e serviços do mundo, daí ser conhecida como "o clube dos ricos". Por sinal, um dos objetivos da OCDE é estimular investimentos nos países periféricos. A organização conta com cerca de duzentos grupos e comitês de estudo que produzem estatísticas e publicações em áreas como agricultura, meio ambiente, educação, comércio e investimentos no exterior. São seus integrantes: Estados Unidos, Alemanha, Áustria, Bélgica, Canadá, Dinamarca, Espanha, França, Grécia, Irlanda, Islândia, Itália, Luxemburgo, Noruega, Holanda, Portugal, Suécia, Suíça, Turquia, Reino Unido, Japão, Finlândia, Austrália, Nova Zelândia, México, República Tcheca, Coréia do Sul, Hungria e Polônia. Constam como itens principais do AMI: a) quanto ao alcance - os investimentos podem incluir todo tipo de bens tangíveis ou intangíveis, inclusive patentes sobre formas de vida, plantas, animais e órgãos humanos; b) quanto aos limites - o AMI não se opõe a que os países regulamentem suas economias internas, desde que os investimentos 
estrangeiros não sofram qualquer tipo de limitação; c) quanto à liberalização - pleno acesso dos investidores estrangeiros aos bens privatizados pelos estados nacionais; d) exceções - quaisquer mecanismos de proteção às economias nacionais serão aceitos apenas temporariamente e deverão ser gradualmente extintos.

6 O bispo Rodrigues, da Igreja Universal, deputado federal por duas legislaturas, divulgou, em reiteradas oportunidades, em jornais de ampla circulação, o seu compromisso com os pobres, com o combate à corrupção e com justiça social. Posteriormente foi descoberto como um dos arquitetos do "mensalão" e participante ativo nos ilícitos ligados às emendas ao orçamento da União. Por sinal, a Igreja Universal contorna a questão do corporativismo perante seus fiéis, por meio da inserção do mandato dos seus candidatos numa suposta "guerra espiritual" em curso. Em outras palavras, os crentes devem votar apenas naqueles candidatos que estejam dispostos a enfrentar as forças "tenebrosas e invisíveis", ou seja, as forças satânicas que estariam presentes na prática política. Tal discurso estabelece um nexo direto entre a prática religiosa dessa Igreja com a atuação dos representantes eleitos, o que, para a massa dos fiéis, se configura como um argumento irrefutável, suficiente e mobilizador. Vale acrescentar que, nas eleições de 2002, a aliança do PT com o PL se sustentava também no argumento em prol da ética na política e no "socialismo de resultados". 